
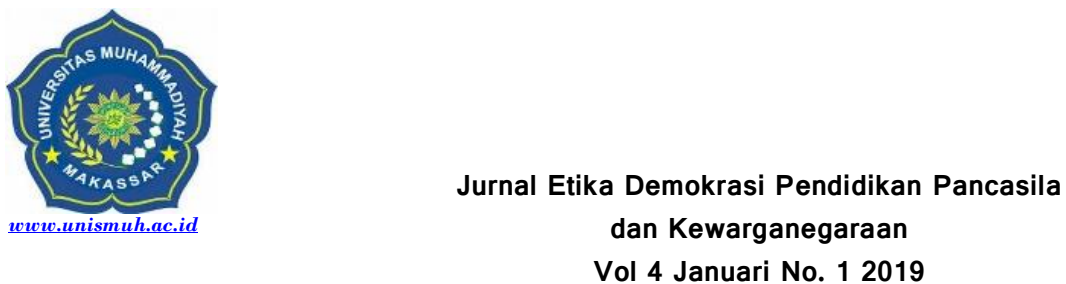

Jurnal Etika Demokrasi

Vol 4 Januari No. 12019

\title{
Analisis Kepatuhan Peserta Didik Terhadap Tata Tertib Sekolah pada SMP Negeri 2 Barombong Kabupaten Gowa.
}

\author{
Nasrun Hasan ${ }^{1)}$, Andi Baso ${ }^{2)} \&$ Siti Aisyah Jamaluddin ${ }^{3)}$ \\ Pendidikan Pancasila dan Kewarganegaraan FKIP Universitas Muhammadiyah Makassar ${ }^{1)}$ \\ Pendidikan Pancasila dan Kewarganegaraan FKIP Universitas Muhammadiyah Makassar²) \\ Pendidikan Pancasila dan Kewarganegaraan FKIP Universitas Muhammadiyah Makassar ${ }^{3)}$ \\ nasrunhasan@unismuh.ac.id ${ }^{1)}{\text { andibaso@unismuh.ac.id }{ }^{2)}}^{\text {sitiaisyahjamaluddin@unismuh.ac.id }{ }^{3)}}$
}

\begin{abstract}
This study aims to find out: 1) Compliance of students with respect to discipline in the SMP. 2 Barombong, 2) Efforts made by the school to foster student compliance with the discipline in the SMP. 2 Barombong. To achieve these objectives, the researchers used the technique of collecting data through documentation, observation, and interviews. Data that has been obtained from the results of the research are processed 1. Compliance of students with respect to discipline in the Public High School. 2 Barombong 2. Efforts made by the school to foster student adherence to discipline in the SMP. 2 Barombong .. This is evidenced by the average student in the SMP. 2 Barombong has obeyed the existing rules so that not many violations occur, while the violations that sometimes arise are only for minor types of violations (not wearing white and white uniforms on Mondays). The factors that form the basis of students' obedience to school discipline are Hedonist, and the type of compliance that belongs to the Hedonist Conformist. 2) Efforts made by schools to foster student compliance with school discipline are divided into 2, namely: 1) Pre-incentive Efforts, which consist of giving / delivering socialization about the importance of student compliance with school discipline, incidental inspection, structuring canteen location. 2) Repressive efforts, which consist of providing strict sanctions against violators, increasing cooperation between BK teachers and homeroom teachers, and supervising individuals (strict supervision / control).
\end{abstract}

Keywords : Analysis, Compliance, School Rules and Students

\begin{abstract}
Abstrak. Penelitian ini bertujuan untuk mengetahui: 1) Kepatuhan peserta didik terhadap tata tertib di SMPN. 2 Barombong, 2) Upaya- upaya yang dilakukan sekolah untuk membina kepatuhan peserta didik terhadap tata tertib di SMPN. 2 Barombong. Untuk mencapai tujuan tersebut maka peneliti menggunakan tekhnik pengumpulan data melalui dokumentasi, observasi, dan wawancara. Data yang telah diperoleh dari hasil penelitian diolah 1. Kepatuhan peserta didik terhadap tata tertib di SMPN. 2 Barombong 2. Upaya- upaya yang dilakukan sekolah untuk membina kepatuhan peserta didik terhadap tata tertib di SMPN. 2 Barombong.. Hal ini dibuktikan dengan rata- rata peserta didik di SMPN. 2 Barombong sudah mematuhi tata tertib yang ada sehingga tidak banyak pelanggaran yang terjadi, adapun pelanggaran yang terkadang muncul yakni hanya pada jenis pelanggaran ringan saja (tidak memakai seragam putih- putih pada hari senin). Faktor yang merupakan dasar kepatuhan peserta didik terhadap tata tertib sekolah adalah Hedonist, dan tipe kepatuhannya tergolong pada Conformist Hedonist. 2) Upaya- upaya yang dilakukan oleh sekolah untuk membina kepatuhan peserta didik terhadap tata tertib sekolah terbagi atas 2 yakni: 1 ) Upaya Prefentif, yang terdiri atas pemberian/penyampaian sosialisasi tentang pentingnya kepatuhan peserta didik terhadap tata tertib sekolah, pemeriksaan secara insidentil, penataan lokasi kantin. 2) Upaya Represif, yang terdiri atas pemberian sanksi yang tegas terhadap pelaku pelanggaran, peningkatan kerjasama guru BK dengan wali kelas, dan pengawasan individu (pengawasan/kontrol yang ketat).
\end{abstract}

Kata kunci: Analisis, Kepatuhan, Tata Tertib Sekolah dan Peserta Didik 


\section{PENDAHULUAN}

Dalam konteks Indonesia, pendidikan telah direformasi menjadi suatu lembaga, dimana dibentuklah sekolah sebagai wadah untuk melakukan proses pendidikan. Sekolah merupakan tempat sosialisasi kedua setelah keluarga, di dalam lembaga pendidikan seorang anak akan berinteraksi dan bersosialisasi dengan lebih luas jangkauannya dibandingkan di dalam rumah atau keluarga serta ada kemungkinan perbedaan kebiasaan dan cara hidup dalam keluarga dan di sekolah.

Sesuai dengan kebijakan pemerintah, pendidikan pada hakekatnya adalah suatu usaha menyiapkan anak didik untuk menghadapi lingkungan hidup yang selalu mengalami perubahan. Pendidikan merupakan usaha dasar untuk mengembangkan kepribadian yang berlangsung di sekolah maupun di luar sekolah. Akan tetapi, dunia pendidikan kita dewasa ini menghadapi berbagai masalah yang amat kompleks yang perlu mendapatkan perhatian khusus bagi kita semua. Salah satu masalah tersebut adalah menurunnya norma- norma agama, kesusilaan, adat istiadat, kesopanan, hukum, kehidupan sosial dan etika moral dalam praktik kehidupan sekolah yang mengakibatkan terjadinya sejumlah perilaku negatif yang sangat merisaukan masyarakat.

Hal tersebut antara lain semakin maraknya penyimpangan berbagai norma- norma agama, kesusilaan, adat istiadat, kesopanan, hukum, kehidupan agama dan sosial kemasyarakatan.

Tujuan pendidikan dapat tercapai secara optimal diperlukan suasana yang mendukung proses belajar mengajar maupun pembinaan pribadi. Dalam kehidupan bersama, hal ini dapat terbentuk dengan adanya aturan hidup bersama yang di sebut tata tertib.

Upaya menciptakan kepatuhan peserta didik terhadap tata tertib yang ada di sekolah adalah untuk mengurangi penyimpangan yang berdampak pada perilaku peserta didik yang juga sebagai alat kontrol atau rekayasa sosial terhadap peserta didik. Sebagaimana diketahui dewasa ini banyak sekali siswa sekolah yang terlibat dalam kenakalan remaja, pergaulan bebas, penggunaan narkoba, tawuran antar sekolah serta penggunaan etika yang salah dalam kehidupan. Oleh karena itu melalui pembinaan tata tertib sekolah diharapkan siswa dibiasakan melaksanakan kehidupan sesuai dengan aturan yang berlaku di masyarakat.

Namun seperti yang di lihat sekarang ini, meskipun dilakukan upaya tersebut terkadang pula tata tertib yang ada dianggap tak berarti apa- apa oleh peserta didik, jangankan untuk dipatuhi meluangkan waktu sedikit saja untuk mengetahui aturan- aturan tersebut pun mereka tak hiraukan. Sikap atau perilaku yang menggambarkan kepatuhan terhadap suatu aturan atau ketentuan merupakan makna dari kedisiplinan. Jadi, pada saat kita menciptakan suatu kepatuhan terhadap aturan atau ketentuan maka akan menghasilkan suatu kedisiplinan.

SMP Negeri 2 Barombong adalah Sekolah Menengah Pertama yang berbasis disiplin, yaitu mulai dari waktu, sikap, dan penampilan. Untuk membentuk karakter yang baik, maka SMP Negeri 2 Barombong membuat peraturan yang sangat ketat, diantaranya adalah semua peserta didik ketika jam 07.15 harus sudah ada di kelas, memakai seragam putih- putih pada hari senin, kaki baju harus dimasukkan, sepatu harus berwarna hitam, serta yang menjadi peraturan unggulan adalah setiap hari senin upacara bendera ada pemeriksaan rambut harus dibawah $2 \mathrm{~cm}$ bagi laki- laki, dan peserta didik perempuan di wajibkan memakai jilbab. Tapi semua dari peraturan ini masih banyak peserta didik yang tidak patuh terhadap peraturan ini, misalnya berangkat telat, baju dikeluarkan, tdak memakai seragam putih- putih pada hari senin, dan memakai sepatu berwarna lain. Sehingga banyak juga sikap karakter peserta didik yang tidak terbentuk dengan baik.

\section{METODE PENELITIAN}

Jenis penelitian ini adalah penelitian deskriptif kualitatif. Pendekatan yang digunakan dalam penelitian ini adalah survey. Penelitian ini dilaksanakan di SMPN 2 Barombong yang beralamat di Desa Kanjilo, Kec. Barombong, Kab. Gowa. Sumber data dalam penelitian ini adalah informan berjumlah 20 orang, tempat atau lokasi, peristiwa, dokumen atau arsip. Populasi dalam 
penelitian ini yaitu 20 orang yang masing- masing 14 orang peserta didik, 1 orang kepala sekolah, 1 orang wakasek kesiswaan, 1 orang guru BK, 1 orang guru mata pelajaran ppkn, 1 orang satpam sekolah, dan 1 orang tukang kantin. Tekhnik pengumpulan sampel dengan cara non- probability sampling. Teknik non-probability sampling yang digunakan adalah purposive sampling. Sampel/objek yang menjadi sumber data adalah 20 orang yang masing- masing 14 orang peserta didik, 1 orang kepala sekolah, 1 orang wakasek kesiswaan, 1 orang guru BK, 1 orang guru mata pelajaran ppkn, 1 orang satpam sekolah, dan 1 orang tukang kantin. Teknik pengumpulan data yang digunakan adalah: observasi, wawancara, dan dokumentasi.

\section{PEMBAHASAN}

\section{Kepatuhan Peserta Didik terhadap Tata Tertib Sekolah}

Kepatuhan peserta didik terhadap tata tertib sekolah di SMPN.2 Barombong berjalan dengan cukup baik. Hal ini dikarenakan pengawasan oleh pihak sekolah yang tegas dan keta sehingga ratarata peserta didik yang ada di SMPN. 2 Barombong sudah mematuhi tata tertib yang ada dan tidak banyak pelanggaran yang terjadi. Dengan adanya kepatuhan terhadap tata tertib maka akan menimbulkan dampak positif bagi peserta didik, salah satunya menciptakan kedisiplinan. Namun dari beberapa aturan- aturan yang tercantum dalam tata tertib di SMPN. 2 Barombong, adapun pelanggaran yang biasanya muncul yakni hanya pada jenis pelanggaran ringan saja seperti tidak memakai seragam putih- putih pada hari senin, berhias yang berlebihan, terlambat masuk dalam kelas. Untuk lebih jelasnya, dibawah ini akan dibahas mengenai kepatuhan peserta didik terhadap tata tertib sekolah mulai dari masuk sampai pulang sekolah.

Pakaian Sekolah

Pakaian sekolah menjadi kewajiban yang harus dilaksanakan peserta didik sebagai identitas seorang pelajar. Pada pelaksanaan jenis aturan ini menemukan ketimpangan. Pakaian sekolah misalnya salah satunya adalah seragam yang harus dipakai mulai hari senin sampai hari sabtu. Pada pelaksanaannya baju seragam, sepatu harus berwarna hitam, kaos kaki putih, lambang, dan atribut.

Di SMPN 2 Barombong, ketidakpatuhan peserta didik dari segi pakaian sekolah misalnya hari senin peserta didik memakai seragam putihputih, hari selasa rabu kamis memakai seragam putih biru, jum'at sabtu seragam pramuka. Akan tetapi pada hari senin masih ada peserta didik yang tidak memakai seragam putih putih.

\section{Rambut dan Make Up}

Rambut dalam hal ini juga merupakan salah satu aturan yang harus dipatuhi oleh peserta didik. Rambut peserta didik pria adalah $2 \mathrm{~cm}$ bagian depan $1 \mathrm{~cm}$ bagian belakang. Berdasarkan observasi, rata- rata rambut peserta didik sudah rapi sesuai dengan ketentuan peraturan sekolah, sebab guru- guru selalu memperhatikan kerapian rambut para peserta didik. Pengawasan kerapian mengenai rambut membuat para peserta didik takut karena terus dipantau oleh guru- guru baik selama proses pembelajaran maupun pada waktu luang. Make up adalah larangan yang diwajibkan bagi siswi untuk tidak memakai make up atau sejenisnya kecuali bedak tipis. Namun dari hasil temuan pada saat observasi menunjukkan larangan ini sedikit kurang diperhatikan oleh pihak sekolah, karena ada beberapa siswi yang memakai make up yang agak berlebihan misalnya bedak yang tebal, lipstick, dan mascara.

\section{Masuk dan Pulang Sekolah}

Kepatuhan terhadap tata tertib mengenai ketepatan waktu datang ke sekolah (upacara bendera) pada hari senin dan hari- hari berikutnya karena jam masuk sekolah lebih cepat dari hari yang lain dimana setiap hari senin dimulai jam 07.10. Ketentuannya peserta didik harus hadir sebelum jam yang sudah ditentukan tersebut. Disamping itu, pengawasan bagi peserta didik yang terlambat cukup diperhatikan oleh guru piket karena pada saat ada peserta didik yang terlambat maka akan langsung diberikan sanksi yakni berdiri tegak menghadap matahari sampai upacara selesai dan juga jika sudah terlambat 15 menit maka langsung disuruh kembali ke rumah. 
Akan tetapi di SMPN 2 Barombong juga terkadang ditemukan ada peserta didik yang terlambat masuk dalam kelas disaat sudah ada guru yang melakukan proses pengajaran. Pada kasus seperti ini, guru mata pelajaran tersebut mengambil tindakan untuk tidak mengizinkan peserta didik yang terlambat untuk mengikuti proses pembelajaran yang sementara berlangsung, terkecuali jika ada izin yang didapat dari guru mata pelajaran sebelum jam pelajaran tersebut. Dan bagi peserta didiki yang tidak diizinkan mengikuti jam pelajaran tersebut harus berada di ruang BK dengan menerima nasehat dari guru BK atas perilakunya.

\section{Kebersihan, Kedisiplinan, dan Ketertiban}

Jenis peraturan ini mengatur tentang keadaan kelas baik sarana dan prasarana yang dipakai untuk menunjang kegiatan pembelajaran. Peraturan ini mewajibkan para peserta didik untuk menjaga dan memelihara perlengkapan kelas. Hasil observasi tentang masalah kebersihan, kedisiplinan, dan ketertiban berjalan dengan sesuai ketentuan yang ada. Misalnya dapat dilihat pada saat jum'at bersih seluruh peserta didik selalu rutin membersihkan baik di pekarangan sekolah maupun di kelas masing- masing walaupun terkadang guru terlambat untuk memberikan arahan. Tempat parkiran tertata dengan rapi sesuai ketentuan yang ada di sekolah. Selain itu, peserta didik membersihkan dalam kelas dan juga pekarangan depan kelas masing- masing sebelum jam pelajaran pertama di mulai, saat jam pelajaran sudah tiba maka peserta didik masuk dalam kelas masingmasing.

Selain dari menjaga kebersihan lingkungan sekolah juga tidak lepas dari ketertiban dan kedisiplinan. Terkait dengan hal ini dapat kita lihat saat ada peserta didik yang ketahuan berkeliaran saat jam pelajaran maka akan ditegur oleh guru piket agar kembali dalam kelas, meskipun dalam satu kelas ada beberapa peserta didik yang mengikuti lomba maka peserta didik yang lain tetap mengikuti proses pembelajaran seperti biasanya dan juga setiap kelas masing- masing memiliki pajangan tata tertib dan visi misi sekolah.

Sopan Santun Pergaulan
Masalah sopan santun pergaulan menjadi sesuatu yang harus dibiasakan untuk menciptakan suasana hubungan antara guru dan peserta didik semakin harmonis. Mengucapkan salam sesama peserta didik dan guru menjadi pemandangan yang hampir dilakukan setiap hari. Kebiasaan ini sudah menjadi adab tertentu dengan orang yang lebih tua. Menghormati sesama peserta didik, menghargai perbedaan agama yang dianut dan latar belakang sosial budaya yang dimiliki oleh masing- masing teman baik di sekolah maupun di luar sekolah.

Sopan santun pergaulan ini menjadi hal yang cukup baik dipahami oleh para peserta didik, baik dengan sesama peserta didik maupun terhadap guru. Karena temuan yang didapat oleh peneliti rata- rata peserta didik di saat bertemu dengan guru langsung memberi salam dengan sopan dan ramah, begitupun pada siswa kelas VII yang selalu bersikap sopan terhadap siswa kelas VIII, dan IX. Sebaliknya bagi siswa senior tetap ramah pula pada juniornya, serta para peserta didik juga saling mengingatkan satu sama lain terkait mengenai peraturan tata tertib sekolah. Bahkan kebanyakan peserta didik juga memiliki interaksi yang baik atau dapat dikatakan akrab dengan beberapa guruguru. Namun disamping itu, peneliti juga menemukan 1 orang siswa laki- laki dari IX.F yang menggunakan bahasa yang ramah dan sopan akan tetapi meski siswa tersebut lumayan pintar juga ternyata sering melakukan pelanggaran terhadap tata tertib sekolah.

Pelanggaran dan Sanksi

Berbagai jenis pelanggaran beserta sanksinya masing- masing mempunyai point dan aturan masing- masing. Peserta didik yang melakukan pelanggaran terhadap ketentuan yang tercantum dalam tata tertib kehidupan sosial sekolah dikenakan sanksi seperti teguran, penugasan, skorsing, dan dikeluarkan dari sekolah. Sanksi ini menjadi bagian yang tak terpisahkan dari jenis pelanggaran. Sanksi terhadap pelanggaran di SMPN 2 Barombong ini berjalan dengan baik karena masing- masing guru piket melaksanakan tugasnya masing- masing dan peran wakasek kesiswaan juga memilki peran yang signifikan, 
sehingga para peserta didik mengatakan peran guru wakasek kesiswaan sangat besar karena bisa membuat para peserta didik takut melakukan pelanggaran.

Upaya- Upaya yang Dilakukan Sekolah untuk Membina Kepatuhan Peserta Didik terhadap Tata Tertib Sekolah.

Kepatuhan peserta didik terhadap tata tertib sekolah menjadi perhatian yang sangat penting jika ingin menciptakan sekolah yang baik, aman, tentram, tertib dan bermartabat. Agar tercipta pembentukan karakter yang baik bagi peserta didik, maka ini bagian yang tak terpisahkan dari kepatuhan terhadap tata tertib sebagai sarana untuk mengontrol peserta didik yang mempunyai perilaku menyimpang. Sehingga untuk tetap menjaga dan meningkatkan kepatuhan peserta didik terhadap tata tertib sekolah di SMPN 2 Barombong ini maka pihak sekolah dengan tegas dan rutin melakukan beberapa upaya- upaya untuk membina kepatuhan peserta didik terhadap tata tertib sekolah yang menjadi perhatian yang sangat penting dalam rangka menciptakan sekolah yang aman, tentram, tertib, dan bermartabat. Untuk lebih jelasnya dibawah ini dapat diperjelas upayaupaya yang dilakukan oleh pihak sekolah untuk membina kepatuhan peserta didik terhadap tata tertib sekolah di SMPN 2 Barombong.

\section{Upaya Preventif}

Pemberian/penyampaian sosialisasi tentang pentingnya kepatuhan terhadap tata tertib sekolah.

Untuk menciptakan kepatuhan peserta didik terhadap tata tertib sekolah tidak mudah dilakukan secepat mungkin, karena hal ini berhadapan dengan banyaknya peserta didik yang harus dibina di sekolah, itupun jika mereka mau mendengar dan terkadang ada peserta didik yang hanya mendengarkan atau memiliki pemahaman terkait tentang ini namun tidak ada nampak aplikasinya. Namun meskipun begitu, pihak sekolah juga tetap melakukan upaya untuk membina kepatuhan peserta didik terhadap tata tertib sekolah, salah satu diantaranya yaitu memberikan sosialisasi tentang pentingnya kepatuhan terhadap tata tertib yang dilakukan pada setiap upacara bendera hari senin, dan bahkan dalam kelas yang biasanya dilakukan oleh kepala sekolah, wakasek kesiswaan, guru BK, guru piket, dan guru mata pelajaran lainnya.

\section{Pemeriksaan secara insidentil}

Pemeriksaan ini diadakan secara tidak terjadwal atau diadakan secara tiba- tiba dan tidak diketahui oleh peserta didik. Biasanya dilaksanakan sekali dalam seminggu. Pemeriksaan insidentil ini adalah salah satu cara untuk mencegah terjadinya pelanggaran, karena pada saat peserta didik berniat untuk membawa barang- barang yang mengganggu proses pelaksanaan pembelajaran dan melanggar tata tertib sekolah maka mereka akan selalu mengingat kalau ternyata ada pemeriksaan insidentil di sekolah dan akan mendapat sanksi yang tegas pada saat ditemukan barang tersebut sehingga pada saat mereka merasa takut, mereka akhirnya tidak membawa barang- barang yang dapat menimbulkan pelanggaran terhadap tata tertib.

\section{Penataan lokasi kantin}

Penataan tempat- tempat sarana dan prasarana sekolah juga penting untuk diperhatikan sebab peserta didik biasanya mencari tempat yang nyaman bagi mereka untuk menemukan kebebasannya seolah- olah tidak ada yang melarangnya. Tempat- tempat seperti ini misalnya kantin, lapangan olah raga dan lapangan yang kosong.

Tempat- tempat ini biasanya dijadikan sebagai tempat untuk melakukan perilaku yang menyimpang/ perilaku yang tidak patuh pada aturan baik secara berkelompok maupun secara perorangan. Harusnya tempat- tempat seperti kantin posisinya dekat dengan ruang guru BK dan ruang guru agar kontrol terhadap peserta didik berjalan dengan baik selama proses pembelajaran hingga pada saat jam istrirahat pula.

\section{Upaya Represif}

Pemberian sanksi yang tegas terhadap pelaku pelanggaran

Berbagai jenis pelanggaran beserta sanksinya masing-masing mempunyai point dan aturan masing-masing. Peserta didik yang melakukan 
pelanggaran terhadap ketentuan yang tercantum dalam tata tertib kehidupan sosial sekolah dikenakan sanksi sesuai ketentuan yang telah ditetapkan oleh sekolah.

Para peserta didik di SMPN 2 Barombong mengatakan bahwa sanksi bagi yang melanggar ketentuan sekolah sangat tegas dan ketat sehingga membuat para peserta didik dapat melatih diri untuk disiplin. Dan juga berperan aktif terus melakukan pengawasan terhadap seluruh peserta didik adalah wakasek kesiswaan yang dominan memantau kepatuhan peserta didik terhadap tata tertib sekolah dan guru piket berfungsi untuk menjaga peserta didik yang terlambat dan juga mengontrol peserta didik jika ada yang berkeliaran pada saat jam pelajaran berlangsung.

Peningkatan kerjasama guru BK dengan wali kelas

Perilaku menyimpang peserta didik pada aturan/tata tertib yang ada di sekolah tidak lepas dari salah satu tanggung jawab dari wali kelas masing- masing kelas yang agar kiranya selalu mengkoordinator para peserta didiknya. Disini wali kelas saling kerjasama dengan guru BK dalam menyelesaikan masalah/ kasus pada setiap peserta didik yang melakukan pelanggaran.

Hubungan kerjasama antar guru BK dengan wali kelas tersebut harus diperkuat dan selalu ditingkatkan, karena bagi peserta didik yang berurusan dengan guru BK maka akan melibatkan wali kelas pula dalam hal untuk tetap menjaga kepatuhan peserta didik terhadap tata tertib sekolah.

\section{Pengawasan individu (pengawasan/kontrol yang ketat)}

Pengawasan ini merupakan pengawasan yang dilakukan oleh wakasek kesiswaan atau guru BK dengan cara memberi tugas kepada beberapa peserta didik yang dipercayainya untuk mengawasi para peserta didik lainnya terkait dengan terjadinya suatu pelanggaran yang dilakukan oleh peserta didik.

\section{KESIMPULAN}

Berdasarkan hasil observasi dan wawancara beserta analisis data, penelitian tentang analisis kepatuhan peserta didik terhadap tata tertib sekolah di SMPN. 2 Barombong kab. Gowa maka dapat di tarik kesimpulan yaitu kepatuhan peserta didik terhadap tata tertib sekolah di SMPN. 2 Barombong berjalan dengan cukup baik. Hal ini dibuktikan dengan rata- rata peserta didik di SMPN. 2 Barombong sudah mematuhi tata tertib yang ada sehingga tidak banyak pelanggaran yang terjadi, adapun pelanggaran yang terkadang muncul yakni hanya pada jenis pelanggaran ringan saja (tidak memakai seragam putih- putih pada hari senin, berhias yang berlebihan). Faktor yang merupakan dasar kepatuhan peserta didik terhadap tata tertib sekolah adalah hedonist, dan tipe kepatuhannya tergolong pada conformist hedonist. Upaya- upaya yang dilakukan oleh sekolah untuk membina kepatuhan peserta didik terhadap tata tertib sekolah menjadi perhatian yang sangat penting dalam rangka menciptakan sekolah yang aman, tentram, tertib, dan bermartabat. Upaya- upaya tersebut yakni: 1) Upaya Prefentif, dan 2) Upaya Represif. Berdasarkan kesimpulan yang sudah dikemukakan di atas, dapat disampaikan saransaran yang perlu menjadi bahan masukan, saran yang dapat diberikan adalah masih perlu ditingkatkan pengawasan yang ketat baik dari pihak sekolah maupun dari pihak orang tua peserta didik sehingga tidak muncul lagi pelanggaranpelanggaran terhadap tata tertib sekolah dan menciptakan kepatuhan yang benar- benar efektif. Peserta didik hendaknya berusaha untuk memahami tata tertib sekolah dan melaksanakan semua aturan tata tertib tersebut serta menjaga kedisiplinan dalam rangka menciptakan sekolah yang aman, tentram, tertib, dan bermartabat.

\section{DAFTAR PUSTAKA}

[1] Darmadi, Hamid. (2011). Metode Penelitian Pendidikan. Bandung: Alfabeta.

[2] Imran, Ali. (2012). Manajemen Peserta Didik Berbasis Sekolah. Jakarta: Bumi Aksara.

[3] Irwan. (2014). Skripsi tentang Pelaksanaan Tata Tertib sekolah di SMK Makassar. Universitas Negeri Makassar

[4] Julyanti Annisa Pratiwi, Zunnun Ferdia Novianti. (2013). Pelanggaran Tata Tertib pada Kalangan Pelajar SMA Negeri 7 Banjarmasin. KTI. Banjarmasin 
[5] Kusmiati, (2004). Tujuan Tata Tertib Sekolah. Jakarta

[6] Lickona, Thomas. (2013). Mendidik untuk Membentuk Karakter:bagaimana sekolah dapat mengajarkan sikap hormat dan tanggung jawab. Jakarta: Bumi Aksara.

[7] Marwan. (2012). "Tata Tertib Sekolah sebagai Sarana Pembentukan Karakter Akhlak Siswa Smp It Abu Bakar Yogyakarta".Skrisi. Jurusan Pendidikan Agama Islam, Fakultas Tarbiyah dan Keguruan, UIN Sunan Kalijaga Yogyakarta.

[8] Mas'udi, (2000). Disiplin Belajar Siswa. Yogyakarta: PT Tiga Serangkai.

[9] Moleong, Lexy J. (2014). Metodologi Penelitian Kualitatif. Bandung: Remaja Rosydakarya.

[10] Peraturan Menteri Pendidikan Nasional No 19 Tahun (2007). "Standar Pendidikan Nasional: Oleh Satuan Pendidikan Dasar dan Menengah Tentang Struktur Organisasi Sekolah,".

[11] Prayitno, (2001). Panduan Kegiatan Pengawasan Bimbingan dan Konseling di Sekolah. Jakarta: Rineka Cipta.

[12] Rumiati, (2007). Pengembangan Pendidikan Surakarta: Departemen (Pendidikan) Pendidikan Nasional.

[13] S. Kaelan, (2002). Pendidikan Pancasila. Yogyakarta: Penerbit Paradigma.

[14] Sugiono. (2014). Metode Penelitian Kuantitatif, Kualitatif, dan R\&D. Bandung: Alfabeta

[15] Sutrisno Hadi. (1986). Metode Penelitian. Yogyakarta: Andi Offset.

[16] Suyanto, (2017). Pengembangan Pendidikan Karakter. Direktorat Pembinaan Guru Pendidikan Menengah, Direktorat Jenderal Guru dan Tenaga Kependidikan. Jakarta: Kemdikbud.

[17] Tirtarahardja, Umar. (2010). Pengantar Pendidikan. Jakarta

[18] W.J.S. Poerwodarminto. (1984). Kamus Besar Bahasa Indonesia. Jakarta: Balai Pustaka

[19] Zuriah, Nurul. (2008). Pendidikan Moral dan Budi Pekerti. Jakarta: Bumi Aksara 